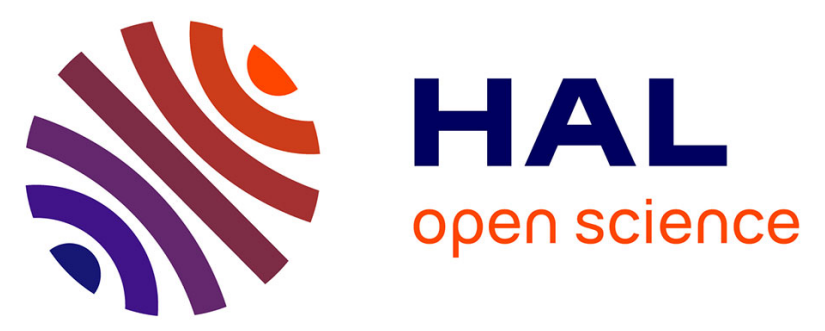

\title{
Strain and Flow Pathways in a Shale Fault Zone: An In-Situ Test of Fault Seal Integrity
}

P Henry, Y. Guglielmi, C. Gout, R. Castilla, P. Dick, F. Donze, A. Tsopela, D. Neyens, L. de Barros, J. Durand

\section{- To cite this version:}

P Henry, Y. Guglielmi, C. Gout, R. Castilla, P. Dick, et al.. Strain and Flow Pathways in a Shale Fault Zone: An In-Situ Test of Fault Seal Integrity. Fifth International Conference on Fault and Top Seals 2019, EAGE, Sep 2019, Palermo, Italy. 10.3997/2214-4609.201902318 hal-02391332

\section{HAL Id: hal-02391332 https://hal.science/hal-02391332}

Submitted on 19 Aug 2020

HAL is a multi-disciplinary open access archive for the deposit and dissemination of scientific research documents, whether they are published or not. The documents may come from teaching and research institutions in France or abroad, or from public or private research centers.
L'archive ouverte pluridisciplinaire HAL, est destinée au dépôt et à la diffusion de documents scientifiques de niveau recherche, publiés ou non, émanant des établissements d'enseignement et de recherche français ou étrangers, des laboratoires publics ou privés. 
Fiche bibliographique

\section{№ dossier: COM20200164}

Référence :

HENRY Pierre, GUGLIELMI Yves, GOUT Claude, CASTILLA Remi, DICK Pierre, DONZE Frédéric, TSOPELA Alexandra, NEYENS Denis, DE BARROS Louis, DURAND Jérémie

Strain and Flow Pathways in a Shale Fault Zone: An In-Situ Test of Fault Seal Integrity

EAGE, Palermo, ITALIE, 2019

(EAGE 2019) 1 -5 | 10.3997/2214-4609.201902318 (C-ACTI)

Auteurs dans l'ordre de la publication:

1, HENRY, Pierre, CORRESPONDING AUTHOR

Centre national de la recherche scientifique, Université Aix-Marseille, Institut de recherche pour le développement, CEREGE, Aix en Provence, France

2, GUGLIELMI, Yves

Centre national de la recherche scientifique, Université Aix-Marseille, Institut de recherche pour le développement, CEREGE, Aix en Provence, France

3, GOUT, Claude

TOTAL, France

4, CASTILLA, Remi

Total (FRANCE), France

5, DICK, Pierre, REFERENT

Institut de radioprotection et sûreté nucléaire, PSE-ENV/SEDRE/LETIS, Fontenay aux Roses, France

6, DONZE, Frédéric

Laboratoire 3SR -Sols, Solides, Structures - Risques, Grenoble, France

7, TSOPELA, Alexandra

Laboratoire 3SR -Sols, Solides, Structures - Risques, Grenoble, France

8, NEYENS, Denis

imaGeau, Clapiers, France

9, DE BARROS, Louis

Univeriste Nice Sophia Antipolis, Geoazur, Nice, France

10, DURAND, Jérémie

SITES, Reuil Malmaison, France

Type : Communication à congrès

Titre : Strain and Flow Pathways in a Shale Fault Zone: An In-Situ Test of Fault Seal Integrity

Résumé d'auteur : A series of small scale (decametric) injection tests were performed in a small fault at IRSN

Tournemire underground laboratory in Toarcian shales. Pressure, induced strains and flow rate were monitored at the injection borehole. Monitoring systems comprising strain sensors and a resistivity streamer were installed in observation boreholes within the fluid invaded zone. A micro-seismic network was also deployed. This experiment shows complex interactions between flow and strain as both appear to be distributed between major discontinuities and the fracture network in the damage and core zones. Permeability variations can be approximated as exponential functions of fluid pressure, with different coefficients below and above a threshold, defining the Fracture Opening Pressure. Hydraulic opening is typically associated with dilatant shearing of fractures. However, the associated strain appears small and largely reversible. Rupture on the main fault plane is triggered after several hours of injection, resulting in a permanent change of flow pathways and flow rate. Numerical modeling based on these experimental results suggest fluid channeling along a fault zone could occur in the subcritical Coulomb regime without fault activation at the larger scale.

Langue : en

$\underline{\text { Communication à congrès : }}$ 
Intitulé du congrès : Fifth International Conference on Fault and Top Seals 2019

Abrégé : EAGE

Lieu : Palermo

Pays : ITALIE

Date de début : 08/09/2019

Date de fin : 12/09/2019

Revue ou ouvrage:

Intitulé de la revue ou ouvrage : Fifth International Conference on Fault and Top Seals 2019 Abrégé ISSN :

Editeur : EAGE

N'ISBN :

NoISSN :

Date de publication : 09/09/2019

Volume :

Numéro :

Pagination : $1-5$

Identifiant DOI : 10.3997/2214-4609.201902318

Informations stratégiques :

Domaine : Secteur 6 - Recherche en Radioprotection

Axe-programme : AP 003/12 - Stockage déchets et aléas naturels

Intitulé du projet :

Type de mesure de protection :

Droits de diffusion :

Existence contrat particulier avec l'éditeur : NON

Conditions générales :

Droits de diffusion / Postprint :

Type de restriction : cannot

Informations :

Délai d'embargo : 0

Unité : day

Droits de diffusion / Version éditeur:

Type de restriction : can

Informations :

Délai d'embargo : 0

Unité : day 


\section{Introduction}

Fault zones cutting through top seals are potential fluid leaks that may be activated by a rise of fluid pressure or tectonic stress. The permeability of fault zones has often been modelled as an exponential function of effective stress (e.g.: Revil and Cathles, 2002). However, permeability variations depend on many other factors including lithology, shear stress and strain, history of fault slip, and healing processes. In order to gain insight on the relationships between permeability, fluid pressure, stress and strain, a series of small scale (decametric) water injection tests were performed in a small fault zone in Toarcian shales at Tournemire IRSN underground laboratory. This fault initiated under extension in the Jurassic and reactivated as right-lateral and then left-lateral strike-slip fault during the Pyrenean compression and has decametric total slip (Constantin et al., 2004; Moreno et al., 2018). Calcite cements seal most of the dilatant fractures that formed during successive episodes of deformation (Lefevre et al., 2016). A fault core is characterized as a scaly fabric zone, comprising thin layers of gouge as well as less deformed lenses. At the location of the injection borehole, the core zone is bounded by fault planes and fracture damage zones extend on either side (Figure 1). The permeability of the intact formation is the $10^{-4}-10^{-6} \mathrm{mD}$ range (Boisson et al., 2001) and long-term experiments performed by IRSN (Dick et al., 2016) show that the fault zone has comparable low permeability, as a consequence of clay self-sealing and calcite cementation. Before injections, the experiment site was instrumented with an array of borehole sensors comprising pressure sensors, strain and resistivity probes and a micro-seismic network (Figure 1). A first result of the injection tests was to show that the hydraulical opening of the fault damage zone is associated with the activation of fractures in a dilatant shearing mode (Guglielmi et al., 2015). This shearing component is in large part reversed during pressure relaxation, which remains intriguing as such a behaviour is not expected if fault slip is a consequence of fluid-pressure-induced normal stress reduction of a shear-loaded fault. Most of the induced deformation was aseismic and the very small seismic events $(\mathrm{M}<-3.8)$ recorded seem to occur on calcified fractures as a consequence of stress transfer (De Barros et al., 2016). Transient P and S wave velocity variations during fluid injections indicate fracture dilatancy within a volume $5-10 \mathrm{~m}$ from the injection point, and stress transfer beyond that zone (Rivet et al., 2016). We will present an overview of results obtained with borehole monitoring systems, addressing the coeval distribution of strain and fluid flow during the experiments and the various factors controlling permeability and its evolution during the tests.

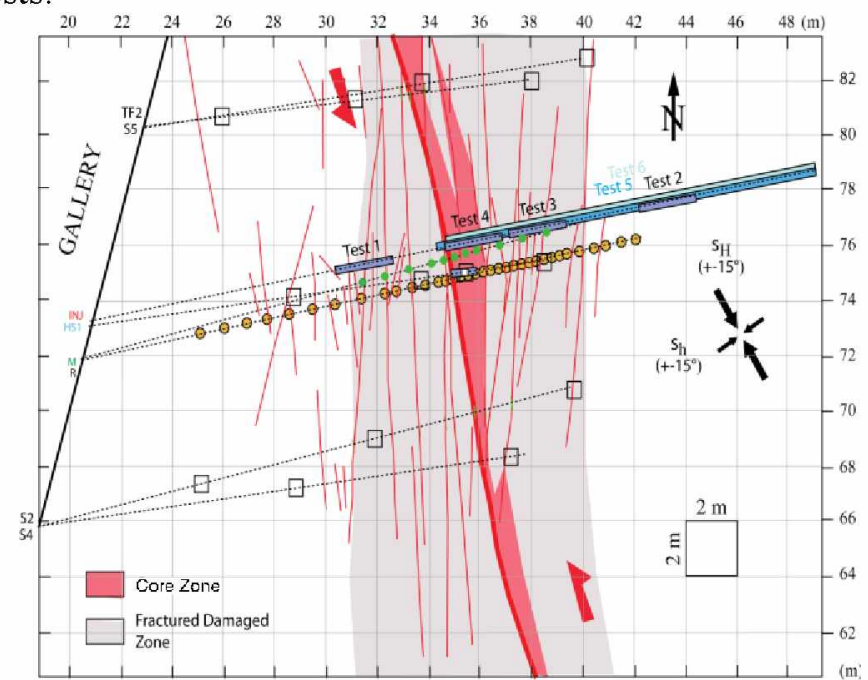

Figure 2 Schematic view of the Tournemire experiment site projected on a horizontal plane. Injection intervals are indicated in blue, M-probe strain gauges positions in green, R-probe electrodes in yellow, borehole accelerometer positions are marked by hollow squares.

\section{Methods}

Series of pulse tests and stepwise injection tests were performed in the fracture damage zone (Tests 1 and 3), core zone (Test 4) and in the intact formation (Test 2) with the SIMFIP probe, a $2.5 \mathrm{~m}$ long 
dual-packer injection chamber equipped in its central part with a 3D optical fibre strain-meter measuring the displacement of borehole walls between 2 sets of anchors $48 \mathrm{~cm}$ apart (Guglielmi et al., 2015). Two longer duration injection tests (12 hours and several days) were performed 2 months later with a single packer pressurizing about $15 \mathrm{~m}$ of open hole (Tests 5 and 6). Permeability during constant pressure or constant flow rate injection tests was estimated with the Dupuis-Thiem formula. Residual permeability after fracture reopening and closure was estimated by fitting pulse tests pressure relaxation curves with analytical solutions (Neuzil, 1982). Flow rates and permeability where found to increase markedly when pressure $P_{\text {inj }}$ in the injection borehole exceeds a threshold (the Fracture Opening Pressure), which varied 1.25 to $3.85 \mathrm{MPa}$ depending on the interval tested. Permeability variations may be modelled as a function of $\left(\mathrm{P}_{\text {inj }}-\mathrm{FOP}\right)$, but with different exponential laws above and below FOP (Figure 2).

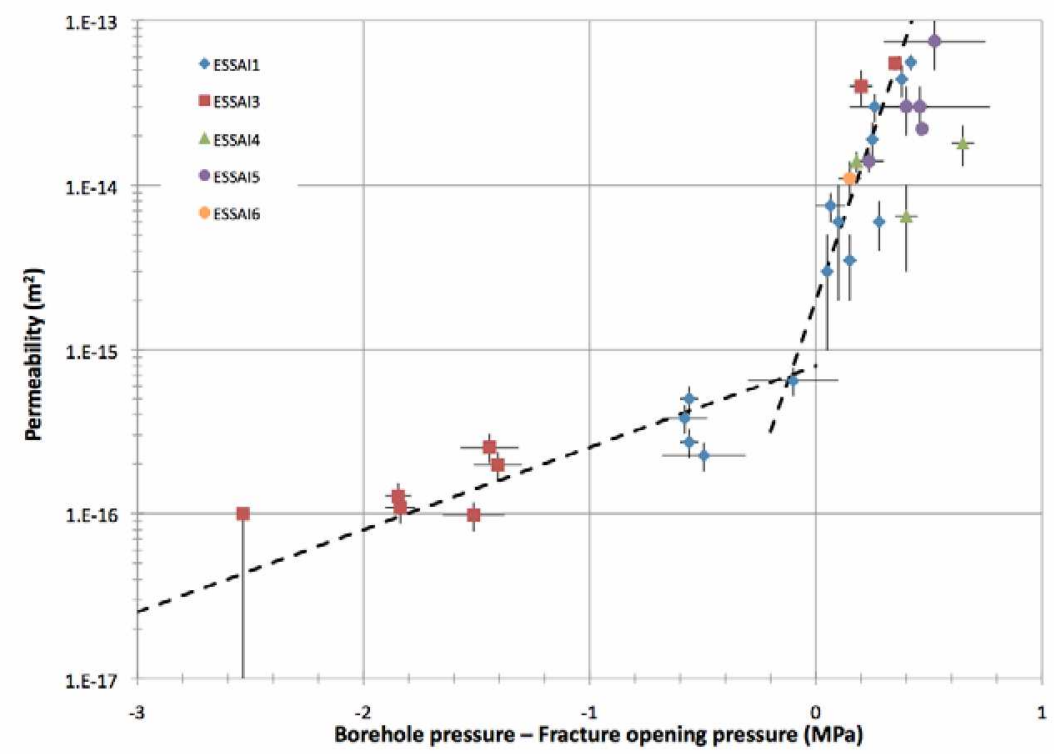

Figure 2 Permeability determinations from pulse tests and flow tests at Tournemire versus excess pressure in injection borehole relative to Fracture Opening Pressure.

Monitoring boreholes $\mathrm{M}$ and $\mathrm{R}$ were drilled about $1 \mathrm{~m}$ from the injection borehole (Figure 1) and surveyed with OPTV, magnetic compass and tiltmeter. The M-probe (mechanical probe) is a $7 \mathrm{~cm}$ diameter ABS tube bound to the formation with bentonite cement instrumented with 44 resistive strain gauges measuring longitudinal strain at 11 sections spaced every 0.5 to $1 \mathrm{~m}$ across the fault zone. This probe thus gives the distribution of axial strain and bending strains in two orthogonal direction, from which the 3-D deformation of the borehole may be reconstructed. The R-probe (resistivity probe) is a flexible cable equipped with annular electrodes of diameter $3 \mathrm{~cm}$ coupled to the formation with bentonite cement of known resistivity ( $5 \mathrm{Ohm} . \mathrm{m}$ after setting). The spacing between electrodes was varied between a maximum of $1 \mathrm{~m}$ in the intact formation to a minimum of $0.3 \mathrm{~m}$ in the central part of the fault zone, with $0.6 \mathrm{~m}$ in intermediate sections. A dipole-dipole protocol is used, that has a radius of investigation of about half the distance between consecutive electrodes. The Rprobe is thus blind to conductivity variations in the injection borehole. The injected fluid $(0.04 \mathrm{~S} / \mathrm{m}$ at $\left.13^{\circ} \mathrm{C}\right)$ is less conductive than the pore water in the formation $(0.2 \mathrm{~S} / \mathrm{m})$ and in the cement $(0.4 \mathrm{~S} / \mathrm{m})$. Flow reaching the R-probe is thus detected as a resistivity increase, at least initially.

The consistency of M-probe and SIMFIP strain measurements could be verified during Tests 3 . Reversible stretching along the borehole was observed above FOP almost simultaneously c.a. $19 \mathrm{~m}$ from the borehole mouth by SIMFIP and M-probe with respective strain amplitudes $4 \times 10^{-5}$ and $2 \times 10^{-}$ ${ }^{5}$. This results from the opening of one or several fractures crossing both boreholes near orthogonally.

\section{Example}


The hydraulic opening of fractures at the FOP was generally associated with coeval strain in the injection and M boreholes. Continuation of injection above FOP resulted in variations of strain distribution, flow rate and resistivity with time reflecting complex interactions. An example of delayed mechanical response occurred during Test 5 , performed with a single packer set at $14.9 \mathrm{~m}, 50$ $\mathrm{cm}$ above the western core/damage zone boundary (Figure 3). Fault opening occurred shortly before midnight (on 06/12) for FOP=3.8 MPa. Almost 3 hours later, strain concentration at the core/damage zone boundary indicate slip along the interface. During this event, flow rate increases by a factor of 4 and FOP decreases to $3 \mathrm{MPa}$. Resistivity monitoring indicates that 3 zones of flow were initially activated, along the edges of the core zone and along fractures initially activated during Test 3 c.a. 19 $\mathrm{m}$. The slip event activates additional flow channels in the western damage zone. These extend further into the intact formation and connect with the excavation damage zone of the tunnel, resulting in leakage into the tunnel, only observed south of the injection borehole. After this test, the packer was pushed $80 \mathrm{~cm}$ down past the core/damage zone interface. During Test 6 , flow zones in the eastern compartment (ca 18 and $19 \mathrm{~m}$ ) were activated again, but no flow occurred across the fault into the western damage zone and toward the tunnel.
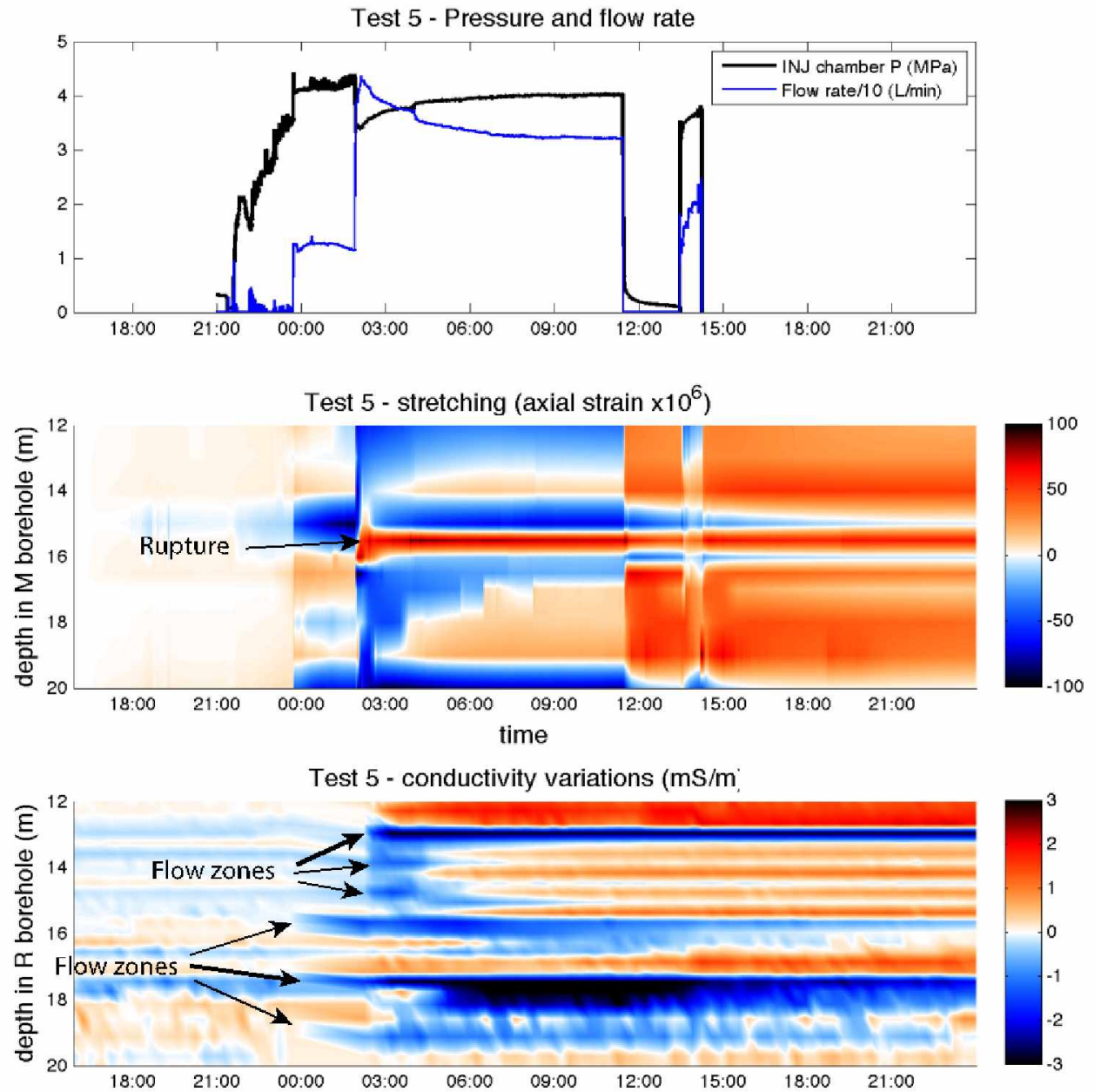

Figure 3 Injection test in Tournemire fault zone performed with single packer pressurizing the borehole from $14.9 \mathrm{~m}$ to its low end. Top: injection parameters. Middle: strain variations measured with M-Probe. Bottom: resistivity variations measured with R-Probe.

\section{Conclusions}

The hydromechanical response of a fault zone in shale cannot be reduced to that of a single fault plane. Part of the strain is localized at major discontinuities (e.g. core/damage zone boundary) but distributed strain is also occurring, including within the core zone. Flow is channeled within the fracture network in the fracture damage zones as well as along these discontinuities. Flow rate and 
permeability increase exponentially with fluid pressure above a pressure threshold (F.O.P. for Fracture Opening Pressure) that seems to depend on local mechanical conditions. Flow pathways and/or their hydraulic conductivity also vary with time during injection tests in association with plastic strains or fault slip. Residual fracture permeability below F.O.P. $\left(10^{-3}\right.$ to $\left.1 \mathrm{mD}\right)$ may allow pressure diffusion along an active fault but is unlikely to allow significant fluid transfer into or out of reservoirs. In tests performed at Tournemire, strain was in large part driven by the volume change caused by fluid injections, rather than by the release of pre-existing ambient stress mediated by effective pressure reduction. This may explain why the induced strains were in large part reversed during pressure relaxation. Flow channels typically open with small, largely reversible strains and channelized flow probably results in highly heterogenous fluid pressure distribution on fault planes. This opens the possibility of transient flow along a fault zone without mechanical destabilization at the larger scale.

\section{Acknowledgements}

This work was supported by TOTAL within the framework of the "Fluid and Fault" project. The authors thank the IRSN (French Institute of Radioprotection and Nuclear Safety) for giving their dedicated help and the access to the IRSN Tournemire underground laboratory.

\section{References}

Boisson, J. Y., L. Bertrand, J. F. Heitz, and Y. M. L. Golvan [2001] In situ and laboratory investigations of fluid flow through an argillaceous formation at different scales of space and time, Tournemire tunnel, southern France. Hydrogeol. J., 9, 108-123, doi:10.1007/s 100400000119.

Constantin, J., Peyaud, J. B., Vergély, P., Pagel, M., and Cabrera, J. [2004] Evolution of the structural fault permeability in argillaceous rocks in a polyphased tectonic context. Physics and Chemistry of the Earth, 29, 25-41. https://doi.org/10.1016/j.pce.2003.11.001

De Barros, L. et al. [2016] Fault structure, stress, or pressure control of the seismicity in shale? Insights from a controlled experiment of fluid-induced fault reactivation. J. Geophys. Res. Solid Earth, doi: $10.1002 / 2015 J B 012633$.

Dick, P., Wittebroodt, C., Courbet, C., Sammaljärvi, J., Estève, I., Matray, J.-M., et al. (2016). The internal architecture and permeability structures of faults in shale formations. The Clay Minerals Society Workshop Lectures Series, 21(17), 227-242.

Guglielmi, Y., D. Elsworth, F. Cappa, P. Henry, C. Gout, P. Dick, and J. Durand [2015] In situ observations on the coupling between hydraulic diffusivity and displacements during fault reactivation in shales. J. Geophys. Res. Solid Earth, 120(11), 7729-7748, doi:10.1002/2015JB012158.

Lefèvre, M., Y. Guglielmi, P. Henry, P. Dick, and C. Gout [2016] Calcite veins as an indicator of fracture dilatancy and connectivity during strike-slip faulting in Toarcian shale (Tournemire tunnel, Southern France). J. Struct. Geol., 83, 73-84, doi:10.1016/j.jsg.2016.01.002.

Moreno, E., Homberg, C., Schnyder, J., Person, A., David, C., du Peloux, A., Moubeche, E., Bonnelye, A., and Dick, P. [2018] Fault imprint in clay units: Magnetic fabric, p-wave velocity, structural and mineralogical signatures. Tectonophysics, 745, 264-277. https://doi.org/10.1016/j.tecto.2018.07.017

Neuzil, C. E. [1982] On conducting the modified 'Slug' test in tight formations. Water Resources Research, 18(2), 439-441. https://doi.org/10.1029/WR018i002p00439

Revil, A. and Cathles, L. M. [2002] Fluid transport by solitary waves along growing faults a field example from the South Eugene Island Basin, Gulf of Mexico. Earth and Planetary Science Letters. 202, 321-335. https://doi.org/10.1016/S0012-821X(02)00784-7

Rivet, D., L. De Barros, Y. Guglielmi, F. Cappa, R. Castilla, and P. Henry [2016] Seismic velocity changes associated with aseismic deformations of a fault stimulated by fluid injection. Geophys. Res. Lett., 43(18), 9563-9572, doi:10.1002/2016GL070410. 